УДК 633.11.631.527, DOI 10.31210/visnyk2018.04.14

(C)2018

Гусенкова О. В., здобувач

(науковий керівник - доктор сільськогосподарських наук, професор Тищенко В. М.)

Тищенко В. М., доктор сільськогосподарських наук, професор

Полтавська державна аграрна академія

\title{
ФОРМУВАННЯ І МІНЛИВІСТЬ СТРУКТУРНИХ ЕЛЕМЕНТІВ УРОЖАЙНОСТІ ПШЕНИЦІ ОЗИМОЇ В УМОВАХ КОНТРОЛЬОВАНОГО СЕРЕДОВИЩА
}

\author{
Рецензент - доктор сільськогосподарських наук, професор П. В. Писаренко
}

Викладено результати чотирьохрічних досліджень (2013-2016 рр.) з вивчення формування $i$ мінливості головного структурного елемента врожайності пшениці озимої - «маса зерна з колосу» (M1) в умовах контрольованого середовища. Як контрольоване середовище використовувалися три строки сівби: ранній (1 вересня, СП-1), оптимальний (15 вересня, СП-2), пізній (1 жовтня, СП-3).

Головною метою досліджень було виявлення генотипів пшениці озимої, які формують максимальну масу зерна з колоса з високим рівнем стабільності незалежно від строків сівби.

У результаті досліджень встановлено, щзо максимальна реалізація генотипів пшениці озимої за ознакою «маса зерна з колосу» відбувається за ранніх строкв сівби. Виділено сорти та селекційні лінї пшениці озимої, які формують «масу зерна з колосу» 3 високим рівнем стабільності, незалежно від строків сівби, і високим ефектом адаптації за иією ознакою. Генотипи пшениці озимої з високим проявом стабільності ознаки «маса зерна з колосу» та високим адаптивним потенціалом за иією ознакою рекомендовані як ичінний секиійний матеріал та як батьківські компоненти при гібридизації для створення нових високопродуктивних сортів пшениці озимої.

Ключові слова: пшениия озима, ознака, генотипи, строки сівби.

Постановка проблеми. Протягом 2013-2016 років у спеціальному досліді за строками сівби ми вивчали формування і мінливість головної ознаки урожайності пшениці озимої - «маса зерна $з$ колоса». В процесі досліджень кожного року відбиралися генотипи пшениці озимої з максимальним рівнем формування М1. Велика увага в аналізах приділялась стабільності утримання рівня формування ознаки «маса зерна з колосу» сортів і селекційних ліній (СЛ) за строками сівби 3 метою залучення таких генотипів в селекційний процес [3, 5, 6, 8].

Аналіз останніх досліджень і публікацій, у яких започтаковано розв'язання проблеми. М. І. Вавилов у своїх наукових працях зауважив, що поряд з генотиповою мінливістю необхідно приділяти увагу взаємодії факторів середовища на інди- відуальну мінливість, яка може пригнічувати навіть спадкові сортові відмінності [1]. В зв'язку з цим у селекції на продуктивність важливе значення надається зональному підходу до складання моделей сорту з визначенням параметрів складових елементів [2]. На думку Писарєва В. С., лише детальне вивчення кількісних ознак, які $є$ елементами комплексної ознаки - продуктивності, дає можливість селекціонерові продумано вести роботу по створенню високопродуктивних сортів [7].

Маса зерна 3 колосу $є$ інтегральною ознакою таких структур як довжина, число колосків і зерен у колосі, маса 1000 зерен, і обумовлена багатьма генами з різним типом взаємодії. У селекційній практиці масі зерна 3 колосу завжди відводилося одне 3 центральних місць. Відбір по колосу є головним принципом роботи багатьох селекціонерів [3]. Його з успіхом застосовував у своїй роботі П. П. Лук'яненко [6]. За даними В. П. Кузьміна [5], В. П. Пьянкова [8], В. Ф. Козловської, В. М. Мельника [4], маса зерна з колоса $є$ провідним структурним елементом у формуванні зернової продуктивності рослини.

Мета досліджень. Головною метою досліджень було виявлення генотипів пшениці озимої, які формують максимальну масу зерна 3 колоса з високим рівнем стабільності, незалежно від строків сівби, для подальшого їх використання в селекційній практиці.

Завдання досліджень. Завданням досліджень було проведення структурного та статистичного аналізів кількісних ознак пшениці озимої, побудова варіаційного ряду та вибірка сортів і селекційних ліній 3 максимальним значенням ознаки «маса зерна з колосу» за трьома строками сівби.

Матеріали і методи досліджень. Матеріалом дослідження були сорти та селекційні лінії озимої пшениці, які вирощувались на селекційних ділянках впродовж 2013-2016 років. По досліджуваних сортах та селекційних лініях (СЛ) проводився структурний аналіз по 25 рослинах, які вирізали на дослідних ділянках, доводили до повітряно-сухого стану та проводили по кожній 


\section{СІЛЬСЬКЕ ГОСПОДАРСТВО. РОСЛИННИЦТВО}

рослині вимірювання, підрахунки, зважування. В аналіз залучали ознаку «маса зерна з колоса». Статистичні обрахунки та проводили за допомогою програми «STATISTICA 10».

Результати досліджень. В 2013 році у великому масиві сортів та селекційних ліній пшениці (107 сортів та СЛ) середнє значення ознаки «маса зерна 3 колоса» (табл. 1) за різних строків сівби було

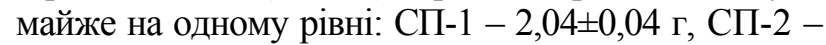

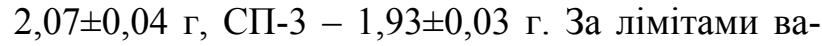
ріювання маса зерна 3 колоса формувалася від 0,87 г (СП-1) до 3,10 г (СП-1). При оптимальному та пізньому строках сівби ознака M1 формувалася майже на одному рівні. Коефіцієнт варіації ознаки «маса зерна 3 колоса» в СП-1 складав $19,5 \%$, в СП-2 та СП-3 був майже на одному рівні.

У досліді 2013 року стабільне значення ознаки M1 за трьома строками сівби утримували 11 сортів та 15 СЛ, які формували масу зерна з колосу від 2,00 г (Іванівська остиста) до 2,92 г (СЛ Перемога $2 \times$ Коломак 5) $\times$ Станічна). Серед генотипів пшениці озимої з максимальним значенням ознаки «маса зерна 3 колосу» слід виділити сорти Лютенька і Славна, а також селекційні лінії СЛ (Перемога $2 \times$ Коломак 5) $\times$ Станічна.

За результатами 2014 року, маса зерна з колосу випробуваних сортів та селекційних ліній пшениці озимої мала середнє значення в межах 2,04 $\pm 0,02$ г (СП-3) - 2,29 $\pm 0,03$ г (СП-1), а за лімітами варіювання - від 1,33 г (СП-2) до 2,87 г (СП-1) (табл. 1). Коефіцієнт варіації ознаки М1 формувався від 11,7 \% (СП-3) до 13,1 \% (СП-2).

Стабільно за строками сівби масу зерна 3 колосу від 2,03 до 2,87 г формували 8 сортів пшениці озимої (Крижинка, Олеся, Зорепад, Славна,
Коломак 3, Золотоглава, Одеська 267, Сагайдак) та 23 СЛ (№ 475, №490, №484, №463, №442, №497, №422, №423, №464, №486, №447, №428, №441, №487, №444, №426, №429, №483, №425, №419, №480, №420, №421). Максимальне значення ознаки формував сорт Сагайдак $(2,40-$ 2,87 г) та селекційні лінії: (Перемога $2 \times$ Коломак $3) \times$ Станічна $(2,44-2,62$ г), (Сонячна $\times$ Коломак 5) $(2,38-2,77$ г), (Еритроспермум $\times$ Находка 4$) \times$ Станічна $(2,58-2,84$ г).

За даними 2015 року, ознака М1 у великому масиві сортів та СЛ пшениці озимої (112 сортів та СЛ) мала середнє значення від 3,06 $\pm 0,04$ г (СП-3) до 3,21 г (СП-1) (табл. 1). За лімітами варіювання між строками сівби також не спостерігалося великої різниці, маса зерна 3 колосу варіювала від 1,96 г (СП-1, СП-3) до 4,35 г (СП-1). Коефіцієнт варіації ознаки M1 був в межах $12,5 \%$ (СП-3)...14,6\% (СП-1).

У 2015 році високий рівень стабільності ознаки «маса зерна 3 колоса» за строками сівби утримували 13 сортів та 37 селекційних ліній пшениці озимої, які формували масу зерна 3 колосу від 3,00 г до 4,35 г. Слід відмітити такі сорти як Тамань, Санжара, Говтва, Самара-2 та селекційні лінії: (Перемога $2 \times$ Коломак 3 ) $\times$ Зерноград 11, F17 Донецька 88×Пемога 2, (F10 (Перемога $2 \times$ Коломак 3$) \times 3$ ерноград 11 , які формували максимальний рівень ознаки «маса зерна 3 колоса.

У процесі аналізу 2016 року у вибірці з 89 сортів та селекційних ліній пшениці озимої маса зерна 3 колоса формувалася в середньому від $2,09 \pm 0,03$ г до 2,15 $\pm 0,04$ г (табл. 1). За лімітами варіювання M1 була в межах 1,26 г (СП-2) - 3,08 г (СП-1). Коефіцієнт варіації складав від 14,8 (СП2) до $16,1 \%$ (СП-1).

\section{1. Формування і мінливість ознаки «маса зерна з колоса» сортів та селекційних ліні пшениці озимої в залежності від року вирощування та строків сівби}

\begin{tabular}{|c|c|c|c|c|c|}
\hline \multirow[t]{2}{*}{ Рік } & \multirow[t]{2}{*}{ Строки сівби } & \multirow{2}{*}{$\begin{array}{c}\text { Кількість сортів та } \\
\text { СЛ }\end{array}$} & \multicolumn{3}{|c|}{ Статистичні показники } \\
\hline & & & $\bar{x}$ & LV & $\mathrm{CV} \%$ \\
\hline \multirow{3}{*}{$\frac{m}{i}$} & СП-1 & 106 & $2,04 \pm 0,04$ & $0,87-3,10$ & 19,5 \\
\hline & СП-2 & 100 & $2,07 \pm 0,04$ & $1,23-2,92$ & 16,9 \\
\hline & СП-3 & 107 & $1,93 \pm 0,03$ & $1,16-2,83$ & 16,3 \\
\hline \multirow{3}{*}{$\stackrel{ \pm}{\stackrel{i}{0}}$} & СП-1 & 66 & $2,29 \pm 0,03$ & $1,69-2,87$ & 11,9 \\
\hline & СП-2 & 90 & $2,14 \pm 0,03$ & $1,33-2,77$ & 13,1 \\
\hline & СП-3 & 89 & $2,04 \pm 0,02$ & $1,51-2,58$ & 11,7 \\
\hline \multirow{3}{*}{$\frac{n}{i}$} & СП-1 & 111 & $3,21 \pm 0,04$ & $1,96-4,35$ & 14,6 \\
\hline & СП-2 & 112 & $3,16 \pm 0,04$ & $2,05-4,07$ & 13,9 \\
\hline & СП-3 & 110 & $3,06 \pm 0,04$ & $1,96-3,97$ & 12,5 \\
\hline \multirow{3}{*}{$\stackrel{\circ}{\stackrel{\circ}{\sim}}$} & СП-1 & 87 & $2,15 \pm 0,04$ & $1,53-3,08$ & 16,1 \\
\hline & СП-2 & 89 & $2,13 \pm 0,03$ & $1,26-3,02$ & 14,8 \\
\hline & СП-3 & 89 & $2,09 \pm 0,03$ & $1,33-2,81$ & 15,3 \\
\hline
\end{tabular}




\section{СІЛЬСЬКЕ ГОСПОДАРСТВО. РОСЛИННИЦТВО}

Максимальне значення ознаки M1 стабільно за трьома строками сівби формували і утримували 20 сортів та 15 селекційних ліній. Серед генотипів 3 високим рівнем формування ознаки «маса зерна 3 колоса» ми виділили сорти Говтва, Радивонівка, Зелений гай, Грація, MV Karej, Альбатрос одеський, Престиж, Лютенька, Левада, Санжара, Астра, Іванівська остиста, Одеська 267, Одеська 51 та селекційні лінії: Лінія 15 × Зерноград 11, Українка полтавська × Срмак, (Перемога $2 \times$ Коломак 3$) \times$ Станічна, Сагайдак $\times$ Левада, (Леля $\times$ Донецька 46) $\times$ Коломак 2, Лорд×Манжелія, Манжелія $\times$ Сагайдак, (Перемога $2 \times$ Коломак 5) × Станічна, Одеська $267 \times$ Донецька 46, (Леля $\times$ Донецька 46) $\times$ Коломак 5 .

За роками досліджень були виділені генотипи, які щорічно, незалежно від строків сівби, стабільно формували максимальне значення ознаки «маса зерна 3 колосу»-СЛ (Перемога $2 \times$ Коломак 3$) \times$ Станічна, СЛ (Перемога $2 \times$ Коломак 5) $\times$ Станічна.

Висновки. У результаті досліджень встановлено, що максимальна реалізація генотипів пшениці озимої за ознакою «маса зерна 3 колосу»

\section{БІБЛІОГРАФІЯ}

1. Вавилов Н. И. Научные основы селекции пшеницы. -М.-Л.: Сельхозгиз, 1935. - 244 с.

2. Долгалев М. П., Крючков А. Г. Зависимость урожайности сортов яровой мягкой пшеницы от хозяйственно-ценных биологических признаков // Вестник ОГУ, 2003. - №1. - С. 74-79.

3. Драгавцев B. A. Генетика количественных признаков в решении селекционных задач: автореф. дис. д-ра биол. наук. - М., 1983. - 36 с.

4. Козловская В. Ф., Мельник В. М. Анализ коэффициентов пути признаков продуктивности скороспельх сортов яровой мягкой пшеницы в Алтайском крае // Селекция и семеноводство в Ал-

\section{ANNOTATION}

Husenkova O.V, Tyshchenko V.M. Formation and variability of structural elements of winter wheat yield under controlled environment

The article presents the results of four-year researches (2013-2016) on the study of the formation and variability of the main structural element of winter wheat yield - "grain mass from ear" (M1) under controlled environment conditions. As controlled environment three sowing periods were used: early (September 1, TS-1), optimal (September 15, TS-2), late (October 1, TS-3), where TS - terms of sowing.

The main purpose of the research was to identify the genotypes of winter wheat, which form the відбувається за ранніх строків сівби.

За ознакою «маса зерен 3 колосу» добори генотипів 3 максимальним значенням ознаки M1 краще проводити за ранніх і оптимальних строків, а добори генотипів із високим рівнем стабільності формування ознаки M1 проводити за трьома строками сівби.

Виділено сорти та селекційні лінії пшениці озимої, які формують «масу зерна 3 колосу» 3 високим рівнем стабільності, незалежно від строків сівби, і високим ефектом адаптації за цією ознакою. За роками досліджень було виділено генотипи, які щорічно, незалежно від строків сівби стабільно формували максимальне значення ознаки «маса зерна 3 колосу» - СЛ (Перемога $2 \times$ Коломак 3) × Станічна, СЛ (Перемога 2 $\times$ Коломак 5) $\times$ Станічна.

Генотипи пшениці озимої з високим проявом стабільності ознаки «маса зерна $з$ колосу» та високим адаптивним потенціалом за цією ознакою рекомендовані як цінний секційний матеріал та як батьківські компоненти при гібридизації для створення нових високопродуктивних сортів пшениці озимої.

тайском крае. - Новосибирск, 1985. - С. 50-60.

5. Кузьмин В. П. Вопросы селекции сельскохозяйственных культур. - М., 1978. - 292 с.

6. Лукьяненко П. П. Возделывание озимой пшеницы на Кубани. - Краснодар: Кн. изд-во, 1957. - $190 \mathrm{c}$.

7. Писарев B. E. Селекция зерновых культур: Избранные работы. - М.: Колос, 1964. - 318 с.

8. Пьянков В. П. Формирование урожая у сортов яровой пшеницы различных экотипов в условиях южной лесостепи Западной Сибири // Селекция и семеноводство яровой пшеницы в Западной Сибири. - Омск, 1984. - С. 26-32.

maximum grain mass from the ear, with a high level of stability, regardless of the terms of sowing.

In the process of research each year genotypes of winter wheat with a maximum formation level of M1 were selected. Much attention in the analyses was paid to the stability of maintaining the level of formation of the sign "grain mass from ear" of varieties and breeding lines (BL) according to the terms of sowing in order to attract such genotypes into the selection process, where $\mathrm{BL}$ is a breeding line.

In the experiment of 2013 the stable value of the M1 trait got 11 varieties and $15 \mathrm{BLs}$, which produced a mass of grain from the ear of $2.00 \mathrm{~g}$ 
(Ivanivska ostysta) to $2.92 \mathrm{~g}$ (BL Peremoha $2 \times$ Kolomak 5) $\times$ Stanichna)

According to the data of 2014 , the maximum value of the sign "mass of grain from ear" formed the Sahaidak sort (from 2.40 to $2.87 \mathrm{~g}$ ) and breeding lines: (Peremoha $2 \times$ Kolomak 3$) \times$ Stanichna $(2.44-$ $2.62 \mathrm{~g})$, (Sonyachna $\times$ Kolomak 5) (2.38-2.77 g), (Erythrospermum $\times$ Nakhodka 4$) \times$ Stanichna $(2.58-$ $2.84 \mathrm{~g})$.

In 2015, the high level of stability of the "grain mass of the ear" got 13 varieties and 37 breeding lines of winter wheat, which formed a mass of grain from the ear from $3.00 \mathrm{~g}$ to $4.35 \mathrm{~g}$.

20 varieties and 15 breeding lines stably formed the maximum value of the M1 trait according to three periods of sowing.

As a result of research it was established that the maximum realization of genotypes of winter wheat on "mass of grain from ear" occurs at early sowing.
The varieties and breeding lines of winter wheat, which form the "mass of grain from the ear" with a high degree of stability, are distinguished, regardless of the terms of sowing and with the high adaptation effect on this basis. Genotypes have been identified, which annually, regardless of the terms of sowing, stably formed the maximum value of the "mass of grain from the ear" - BL (Peremoha2 $\times$ Kolomak 3 ) $\times$ Stanichna, BL $($ Peremoha $2 \times$ Kolomak 5) $\times$ Stanichna.

The genotypes of winter wheat with a high stability manifestation of the "mass of grain from the ear" and high adaptive potential on this basis are recommended as valuable selection material and as parent components in hybridization for the creation of new high-yield winter wheat varieties.

Key words: winter wheat, sign, genotypes, sowing terms. 